\title{
REgENERATION OF GaRLIC PLANTS (ALLIUM SATIVUM L., CV. "CHONAN") VIA CELL CULTURE IN LIQUID MEDIUM
}

\author{
LUIS PEDRO BARRUETO CID, ${ }^{1}$ ROLF DIETER ILLG, ${ }^{2}$ aND AQUILES E. PIEDRABUENA ${ }^{2}$ \\ Department of Genetics and Evolution, I.B., University of Campinas, S.P. Brazil
}

(Received 16 July 1993, accepted 7 April 1994; editor M. A. W. Hinchee)

\begin{abstract}
SUMmARY
Aiming at the genetic improvement of garlic cultivars, a cell suspension protocol was established which includes the induction of friable callus, establishment of cells in liquid medium, plating, regeneration, and bulb formation. Calluses of various textures from compact to friable and from green to yellowish were obtained by culturing explants excised from inner leaves of garlic bulbs on Marashig-Shoog (MS) medium with 2,4 dichlorophenoxy acetic acid (2,4-D), (1.1 mg/liter [5.0 $\mu \mathrm{M}]$ ), picloram $(1.2 \mathrm{mg} /$ liter [5.0 $\mu \mathrm{M}])$, and kinetin $(2.1 \mathrm{mg} /$ liter [10 $\mu \mathrm{M}])$. Friable callus occurred on MS-A contained 2,4-D alone (1.0 mg/liter [4.52 $\mu M]$ ) and this callus was used to develop cell suspension cultures, which were maintained in liquid MS-B medium with a 2,4-D/benzyl adenine (BA) $(0.5 \mathrm{mg} /$ liter [2.25 $\mu M$ ]: $0.5 \mathrm{mg} / \mathrm{liter}$ [2.22 $\mu M$ ]) ratio. High plating efficiency was obtained on MS-C medium with different naphthalene acetic acid/BA combinations. Regeneration occurred after transfer of the caulogenic mass to MS-C medium containing $10 \mathrm{mg} / \mathrm{liter}(74.02 \mu M)$ and 20 $\mathrm{mg} / \mathrm{liter}(148.04 \mu M)$ adenine for 60 days, followed by transfer to adenine-free medium. Plantlets transplanted to soil showed normal phenology. Shoots grown on modified MS medium supplemented with indolylbutryic acid $(3.0 \mathrm{mg} / \mathrm{liter}$ [14.7 $\mu M]$ ) stimulated bulb formation by 30 days in culture.
\end{abstract}

Key words: Allium sativum L.; cell suspension; regeneration; bulb formation.

\section{INTRODUCTION}

Traditional breeding methods are not applicable to garlic because the species produces sterile flowers and can only be propagated vegetatively (Novák and Havránek, 1975). Therefore the development of in vitro alternatives for genetic improvement of garlic cultivars would be helpful and desirable. One possibility is the use of cell suspension cultures to screen cells for genetic and physiologic characteristics, selection of desirable somaclonal variants, and introduction of foreign genes via transformation procedures. The goal of this paper was to establish a practical regeneration protocol from garlic cell suspension cultures that could be used to select new genotypes with improved, agronomically important traits.

Usually, solid medium has been used for in vitro plant regeneration of garlic (Havránek and Novák, 1973; Kehr and Schaeffer, 1976; Novák, 1983). Reports of suspension cultures, on the other hand, are uncommon in this species and even the paper by Nagasawa and Finer (1988), one of the first reports on this subject, did not report in vitro regeneration of plantlets.

\section{Material and Methods}

Stock cultures of garlic callus was used for this study. Five steps for the regeneration of plants via cell suspension were established: induction of

\footnotetext{
${ }^{1}$ Present address: CENARGEN/EMBRAPA, Cx.P. 02372, CEP 70849-970, Brasília/DF, Brazil.

${ }^{2}$ Department of Genetics and Evolution, Cx.P. 6109. I.B., University of Campinas, CEP 13081, Campinas/SP, Brazil.
}

friable callus, establishment of a liquid cell suspension, plating, regeneration, and bulb formation.

Establishment and maintenance of stock cultures. The initial explants of Allium sativum L. "Chonan", were obtained from proximal portions of leaves still enclosed in small bulbs and cultured on callus initiation medium containing MS salts (Murashige and Skoog, 1962), supplemented with $3.0 \%$ (wt/vol) sucrose, $0.75 \%(\mathrm{x} / \mathrm{vol})$ agar, and $(\mathrm{mg} /$ liter) $1.12,4$-dichlorophenoxyacetic acid (2,4-D), 1.2 4-amino-3,5,6-trichloropicolinic acid

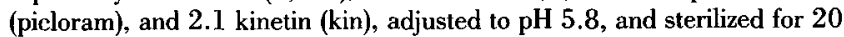
min at $1.0 \mathrm{~kg} / \mathrm{cm}^{2}$ and $120^{\circ} \mathrm{C}$. Growing callus was maintained on MS medium with $5.6 \mathrm{mg} /$ liter $\mathrm{N}^{6}$-benzyladenine (BA). The cultures were illuminated with cool white fluorescent light for $16 \mathrm{~h} /$ day and $50 \mu \mathrm{E} \cdot \mathrm{m}^{-2} \cdot \mathrm{s}^{-1}$ at a constant temperature of $26^{\circ} \pm 2^{\circ} \mathrm{C}$. Callus cultures were subcultured at 4 wk intervals.

Friable callus induction. Compact and vigorous green stock callus was transferred to MS-A medium containing MS salts and (in $\mathrm{mg} / \mathrm{liter}$ ) calcium pantothenate (1.0), pyridoxine $\cdot \mathrm{HCl}(1.0)$, thiamine $\cdot \mathrm{HCl}(1.0)$, nicotinic acid (1.0), inositol (100), sucrose (30000), casein hydrolysate (250), agar (7500), and 2,4-D (1.0). The callus cultures were subcultured every $4 \mathrm{wk}$.

\section{Establishment of the suspension culture}

Preparation of the inoculum. Quantities of 5 to $7 \mathrm{~g}$ of friable callus were transferred into 250-ml Erlenmeyer flasks containing $50 \mathrm{ml}$ of MS-B medium containing MS salt with $1 / 3 \times \mathrm{NH}_{4} \mathrm{NO}_{3}$ and $1 / 2 \times$ Fe-EDTA plus (in mg/liter) calcium pantothenate (3.0), pyridoxine $\cdot \mathrm{HCl}(3.0)$, thiamine $\cdot \mathrm{HCl}(3.0)$, nicotinic acid (3.0), inositol (100), sucrose (20 000), L-glutamine (146), 2,4-D (0.5), and BA (0.5). The growth regulators, vitamins, and L-glutamine were filter-sterilized, using a cellulose acetate membrane (Millipore) with a pore diameter of $0.22 \mu \mathrm{m}$, and added to the already cooled, autoclaved medium. 
Calluses in liquid suspension culture (MS-B) medium were incubated at $26^{\circ} \pm 2^{\circ} \mathrm{C}$ in the dark with continuous agitation at 120 rpm. A week later, the cultures were filtered through a 800- $\mu \mathrm{m}$ pore screen. The filtrates were placed in beakers and transferred to a 250-ml Erlenmeyer flask. After sedimentation of the cell, $80 \%$ of the medium was discarded and replaced by fresh MS-B, maintaining the initial volume of $50 \mathrm{ml}$. The flasks were submitted to agitation at $120 \mathrm{rpm}$ during 15 days; $40 \%$ of the medium was replaced twice a week.

Growih curves: 2,4-D/BA effect. For the establishment of growth curves, $10 \mathrm{ml}$ of cell suspension (approximately $35 \mathrm{mg}$ dry weight) from stock flasks were added to $40 \mathrm{ml}$ of MS-B medium in a 250-ml Erlenmeyer flask. Six combinations of 2,4-D/BA were added to the MS-B medium (in mg/liter) $0.0 / 0.0,0.5 / 0.0,0.0 /$ $0.5,0.5 / 0.5,1.0 / 0.5$, and $2.0 / 0.5$, with four replications per treatment; $40 \%$ of the medium was replaced twice a week. The $\mathrm{pH}$ and cell growth were monitored once a week during $5 \mathrm{wk}$. During this period the flasks were incubated as described above.

Follow-up study of cell growth in the suspension. The effect of different 2,4-D/BA treatments on cell growth population was as-
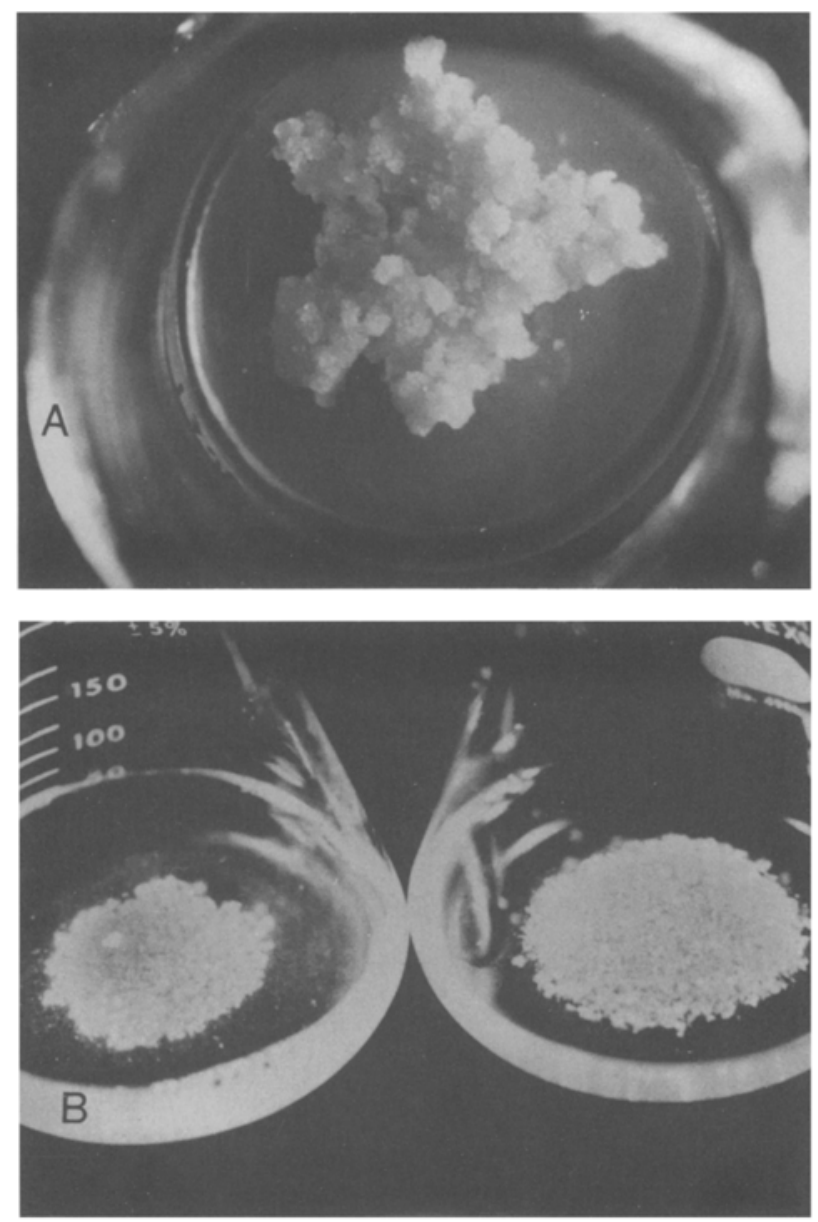

Fig. 1. A, friable callus of garlic originated from compact callus, subcultured periodically on MS-A medium; $B$, cell suspension at plateau phase, in Week 5, showing the cellular sediment.
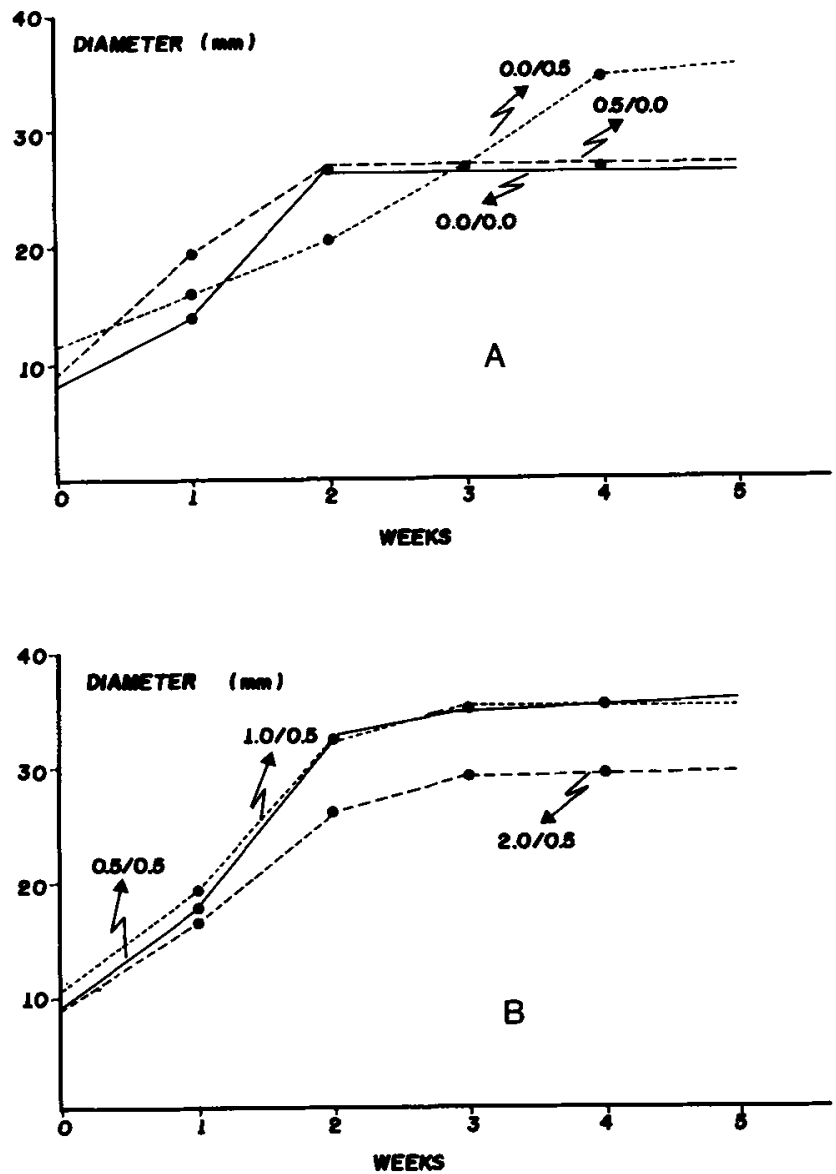

Fig. 2. Effect of different concentrations of 2,4-D/BA on the growth of garlic, as measured by cellular sedimentation of the cell suspension. $A$, lower concentrations, $\mathrm{mg} / \mathrm{liter} 0.0 / 0.0,0.0 / 0.5$, and $0.5 / 0.0 ; B$, higher concentrations, $\mathrm{mg} / \mathrm{liter} 0.5 / 0.5,1.0 / 0.5$, and $2.0 / 0.5$.

sessed according to Barrueto Cid and Illg (1990), as follows: once a week, the flasks were shaken manually for $5 \mathrm{~s}$ approximately and placed over a ruler. Because of the agitation, the cellular sediment acquired a circular form at the bottom of the Erlenmeyer flask, and the size of the diameter was quickly measured. This procedure was done 3 times per flask, for each of the four repetitions of the treatments. Once the readings were concluded, the flasks were returned to the shaker. The statistical evaluation of the data was obtained by analysis of variance and Tukey's test at $5 \%$ level.

\section{Cellular plating}

For this study the medium composition MS-C was MS salts with $1 / 2 \times$ Fe-EDTA, vitamins according to MS-B, but autoclaved, and (in $\mathrm{mg} /$ liter) inositol $(100)$, sucrose $(20000)$, casein hydrolysate (500), Difco-agar (5600), and naphthaleneacetic acid (NAA), and $\mathrm{BA}$ in the following combinations $0.0 / 0.0,0.0 / 0.5,1.0 / 0.0,1.0 /$ $0.5,1.0 / 1.0$, and 1.0/2.0.

Five petri dishes $(10 \times 100 \mathrm{~mm})$ per NAA/BA treatment containing $30 \mathrm{ml}$ of the semisolid medium were used. Thereafter, $2 \mathrm{ml}$ of cell suspension in the exponential phase of growth, 15 days old, 

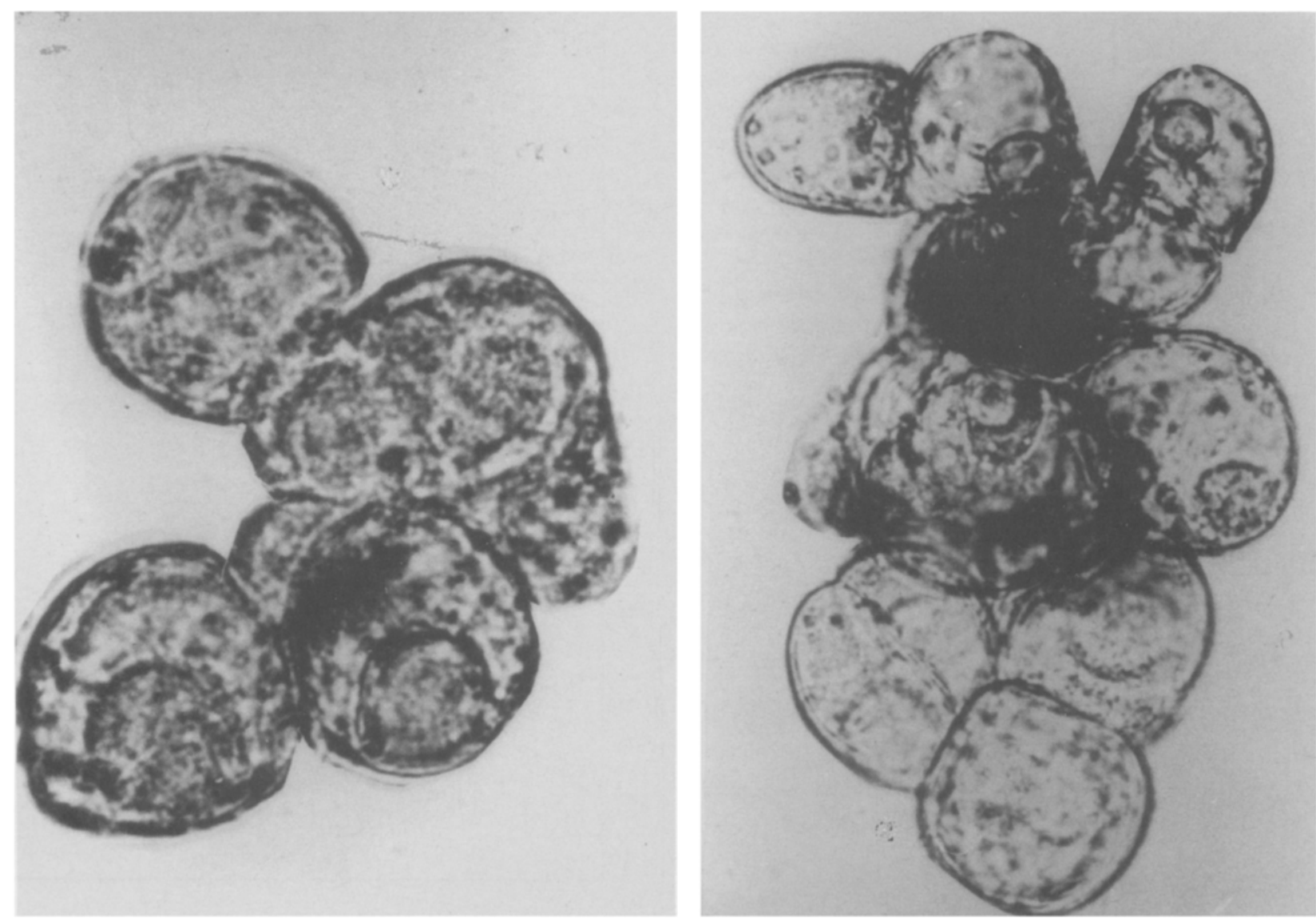

FIG. 3. Microscopic aspect of garlic cells in suspension in MS-B medium and exponential phase.

were injected into the medium using a syringe. The petri dishes were sealed and maintained at a photoperiod of $16 \mathrm{~h}$ and a temperature of $26^{\circ} \pm 2^{\circ} \mathrm{C}$ for 45 days. An additional treatment was included by supplementing the MS-C medium with $10 \mathrm{mg} / \mathrm{liter}$ of adenine. This medium was dispensed into $10 \times 100-\mathrm{mm}$ petri dishes at a rate of $30 \mathrm{ml}$ per plate. A filter paper $9 \mathrm{~cm}$ in diameter was placed over the nutrient medium, and then $2 \mathrm{ml}$ of cell suspension was poured on the filter paper.

\section{Regeneration}

Callus originating from different treatments of the plated cultures was transferred for 30 days to a culture medium containing MS salts, vitamins (autoclaved) at one third the concentration of MS-B, and (in mg/liter) inositol (100), commercial sugar (20 000), casein hydrolysate (500), and agar (5600). The light and temperature conditions were the same as for the plating culture condition (standard).

After 30 days the calluses were transferred to MS-C medium supplemented with $10 \mathrm{mg} /$ liter of adenine. After 30 days they were transferred to MS-C medium with $20 \mathrm{mg} /$ liter of adenine for the same period. The calluses were returned to the MS-C medium, but without growth hormones, under standard conditions of light, temperature, and periodic transfer intervals.
Shoot growth. After approximately 60 days the calluses with their respective shoots were transferred to MS-C medium with and without Maizena (corn starch). The Maizena was used at $7.0 \%$, and agar was not included in these media. Sixteen flasks were used per treatment and were placed under laboratory temperature and light conditions for 60 days.

Bulb induction. Plants that had already been through the MS-C medium with and without Maizena were transferred to the basic maintenance medium MS-D. Developing shoots, about 10 to $15 \mathrm{~cm}$ long, were transferred and maintained for 30 days on a medium containing $3.0 \mathrm{mg} /$ liter of indolylbutyric acid (IBA) for bulb formation. The basic maintenance medium (MS-D) consisted of MS salts with $1 / 2 \times$ macronutrients, $1 / 2 \times$ FeEDTA, and (in mg/liter) $\mathrm{KH}_{2}$ $\mathrm{PO}_{4}(170)$, commercial sugar $(60000)$, agar (5600), and no vitamins.

\section{Results and Discussion}

After 30 to 60 days, on MS-A medium, the compact callus with green pigmentation started to change to a friable form with a beige or yellowish color (Fig. $1 \mathrm{~A}$ ). Probably this change was related to a high exogenous auxin:cytokinin ratio that could have favored the loss of chlorophyll (Berlyn and Zelitch, 1975; Husemann and Barz, 1977) and increased the friability of the tissue (Besse et al., 1992). 

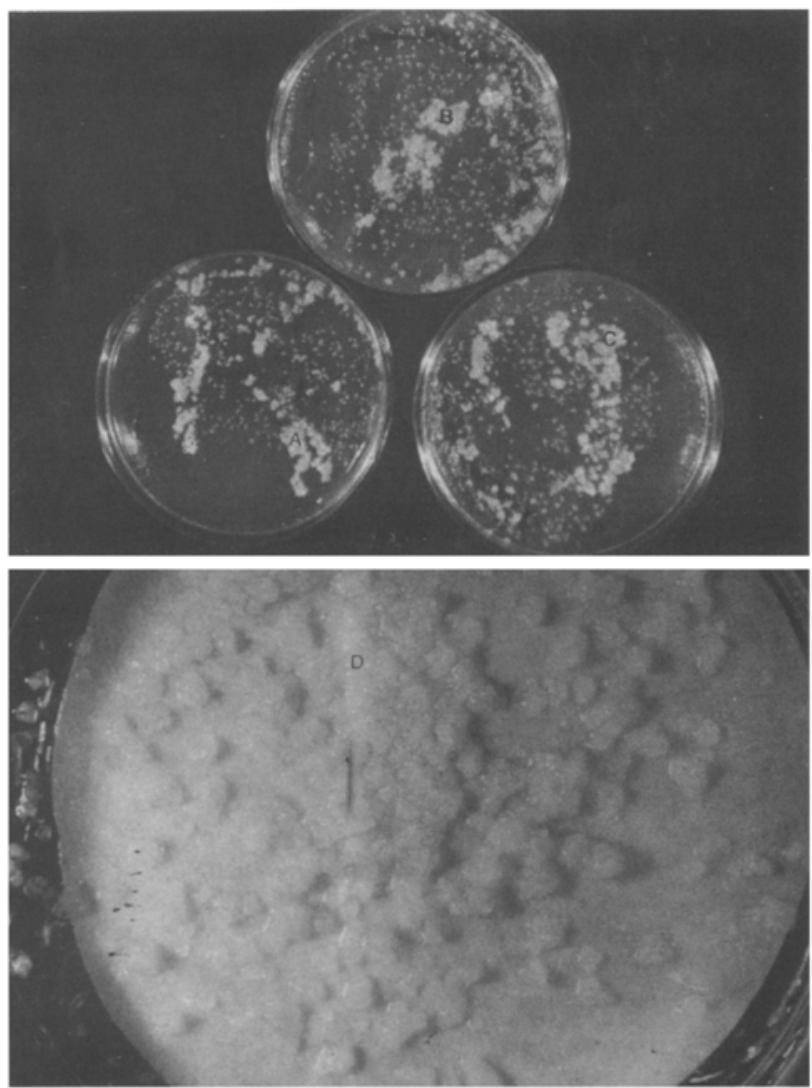

Fic. 4. Plating of garlic cells from suspension after 45 days in MS-C medium. Top: different combinations of NAA/BA (mg/liter) $A 0.0 / 0.0 ; B$ $1.0 / 0.0 ; C 1.0 / 0.5$. Botlom: $D$, plating on filter paper in MS-C medium plus $10 \mathrm{mg} /$ liter of adenine.

Cell suspension cultures were established from these cultures (Fig. $1 B$ ) because attempts to use compact callus to establish suspensions were unsuccessful.

The procedure of monitoring growth by measuring the size of the

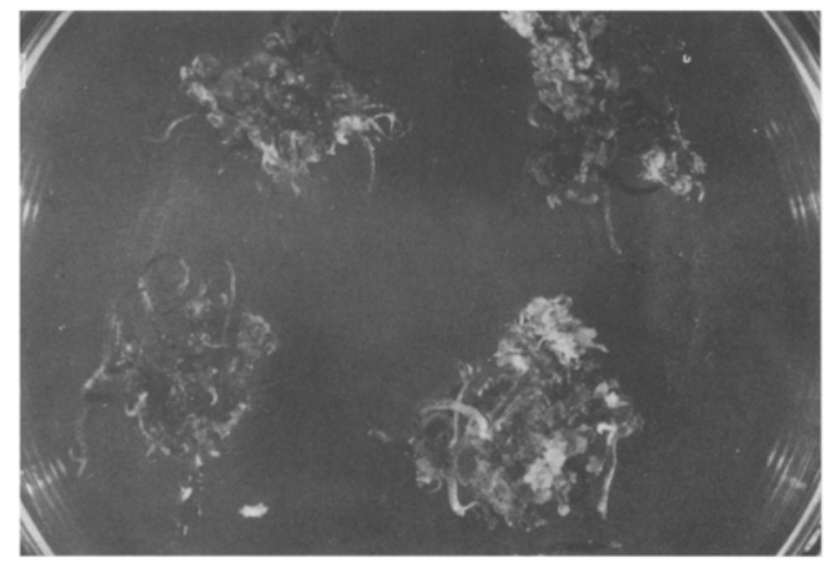

Fic. 5. Callus regeneration of garlic on MS-C medium without growth regulators, after being subcultured in 10.0 and $20.0 \mathrm{mg} /$ liter of adenine.
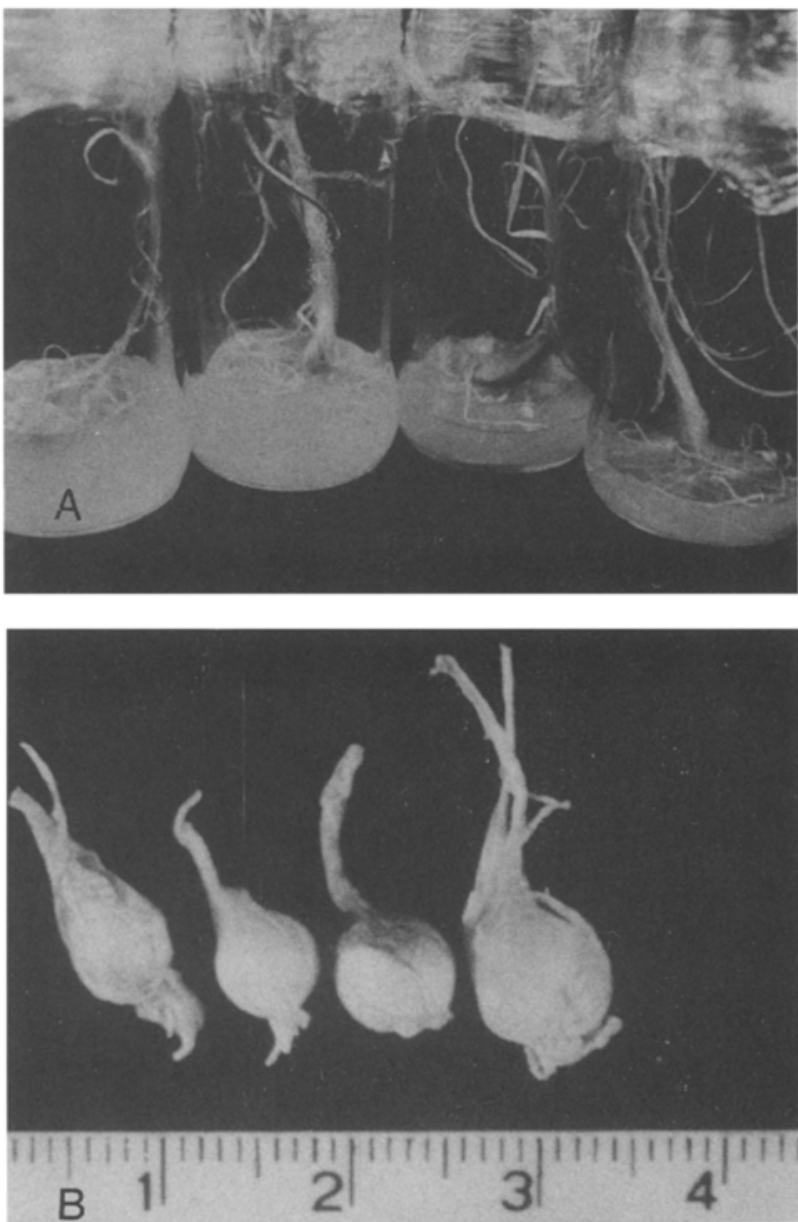

Fig. 6. $A$, plants showing rooted bulbs of garlic; $B$, bulbs collected from $A$.

diameter of the cellular sediment seems to be better than any of the others used (Fresh or dry weight, PCV, number of cells, etc.) because it is much simpler, not disruptive, and appropriate for the

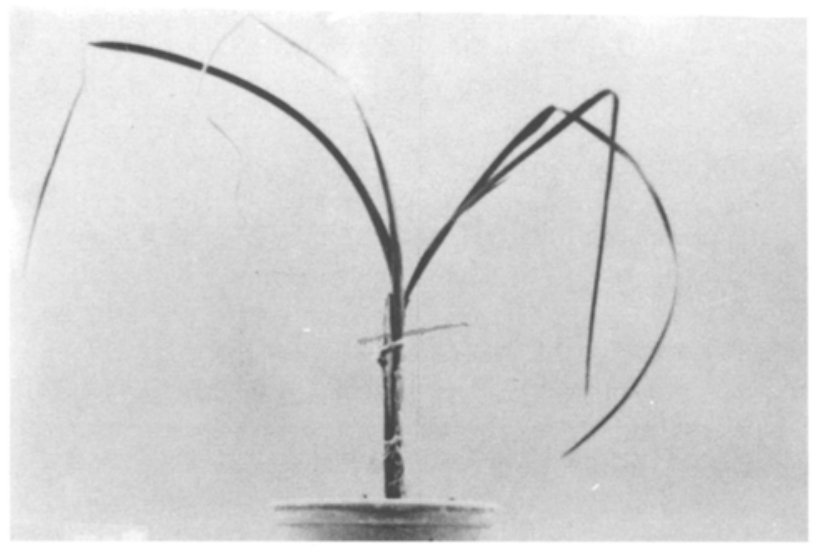

Fig. 7. Garlic plant regenerated from plated cells and transferred to soil before bulb formation. 
Chonan cell suspension because in liquid medium this cultivar forms conspicuous aggregates that, when shaken and allowed to settle, form a flat circular mass with a definite outline.

The growth curves obtained with this method exhibited two phases (Fig. $2 A, B$ ): one exponential and the other stationary or plateau. This growth pattern is conservative and is also found in other species and with different monitoring procedures (Smolenskaya et al., 1989; Blom et al., 1992). The statistical analysis of the data indicated that the values at plateaus level (Fig. $2 A$ ) in the 2,4-D/BA $0.0 / 0.5$ treatment were significantly different from those obtained with the other treatments. On the other hand, the growth on treatments with $1.0 / 0.5$ and $0.5 / 0.5$ was different from that on $2.0 / 0.5$ (Fig. $2 B$ ) at the plateau level. The average of the maximum sediment diameter value, at the plateau level (Fig. $2 \mathrm{~A}$, $B$ ), was similar for the combinations $0.0 / 0.5,1.0 / 0.5$, and 0.5 / 0.5 . One should point out that the coefficient of variability of the data of the variance analysis for the same figures were 8 and $11 \%$, respectively, showing small variation in the diameter of the sediment per treatment. This indicates that the method used to evaluate cell growth was adequate.

For routine preparation of cell suspensions, the combination of 2,4-D/BA $0.5 / 0.5 \mathrm{mg} /$ liter was selected, although there were no statistical differences with respect to the other combinations tested (Fig. 2 B: 1.0/0.5). The combination of $0.0 / 0.5 \mathrm{mg} /$ liter was discarded because, compared to the combination $0.5 / 0.5$ and 1.0 / $0.5 \mathrm{mg} /$ liter, it caused slower growth and after 28 days showed a cellular mass equivalent to that obtained with the other concentrations at 15 days (Fig. $2 A, B$ ). Poor results with respect to plating efficiency were also obtained for the combinations of 2,4-D/BA: $0.0 / 0.0 \mathrm{mg} / \mathrm{liter}, 0.5 / 0.0 \mathrm{mg} / \mathrm{liter}$, and $2.0 / 0.5 \mathrm{mg} / \mathrm{liter}$ after 15 days.

Fifteen-day-old cells (Fig. 3) were small, round, isodiametric, and formed small aggregates in which the nucleus was easy to visualize. Some cells undergoing cytokinesis were seen. Tubular cells were uncommon. The increase in diameter of the sediment mass is attributed to the meristematic characteristics of the cells observed in the exponential phase of the curves, especially in the combinations of 2,4-D/BA where larger diameters were formed. Concomitant with these increases, in most cases the $\mathrm{pH}$ of the medium dropped in this phase and increased in the plateau phase. The $\mathrm{pH}$ variation seems to be a frequent phenomenon in cell suspension culture (Katoh et al., 1979; Dubois et al., 1988; Schmitz and Lörz, 1990) and in some systems can occur simultaneously with the rise of endogenous levels of some components of the polyamine "pool" (Evans and Malmberg, 1989).

In the MS-C medium used for plating, all treatments showed cellular proliferation and micro-callus formation (Fig. $4, A-C$ ), including the control (0.0/0.0 NAA/BA), 45 days after inoculation. This suggests that the cells used as inoculum were physiologically competent for mitotic division. The 15-day culture period (exponential late phase of growth), the composition of the MS-C medium, and the volume used per flask were adequate for successful plating. Although the different treatments with NAA/BA presented very similar results, in terms of induction and callus proliferation, the combination of $1.0 / 0.5 \mathrm{mg} /$ liter was chosen for routine work. The plating onto filter paper offered good results (Fig. $4 D$ ) too, as reported by others (Horsch, 1984; Chowdhury and Vasil, 1992).

Regeneration was satisfactory (Fig. 5), although the cultivar used was considered to be recalcitrant. The shoots were green, thin, and short, measuring approximately $30 \mathrm{~mm}$ in length at 60 days. These results are encouraging not only because of the callus regeneration rate, but also because of the lack of shoot vitrification. On the other hand, it is the first time that adenine is successful used in garlic plant regeneration (Kerh and Schaeffer, 1976; Abo El-Nil, 1977; Novák et al., 1985; Illg and Siqueira, 1986; Nagasawa and Finer, 1988).

Shoot growth in the medium containing Maizena was similar or slightly superior to the control. This result represents an advantage for routine work with in vitro propagation because its cost is lower than the cost of the agar. The shoots developed normally on the MS-D maintenance medium and formed prominent bulbs, which rooted (Fig. $6 \mathrm{~A}$ ). Bulb formation was a consequence of the stimulating action of sucrose and IBA in the concentrations used. This observation agrees with published results (Vince-Prue, 1975), even overcoming the photoperiodic effect, because plants with low sucrose levels $(3.0 \%)$ and without IBA normally showed less bulb formation at a $16-\mathrm{h}$ photoperiod. When the plants started to dry (Fig. $6 \mathrm{~A}$ ), the bulbs were harvested (Fig. $6 \mathrm{~B}$ ) and stored in paper bags at room temperature. Some flasks were contaminated during the process of bulb formation, these plants were transferred to the soil, where they developed a normal cultivar phenotype (Fig. 7).

\section{ACKNOWLEDGMENTS}

Our thanks to EMBRAPA and CNPq, Brazilian Government Institutions, for the financial support. Our thanks also to Drs. Linda Caldas, A. C. Torres, Eugen Gander, and Agronomic Engineer Claudia Ferreira for their comments and suggestions on the manuscript.

\section{REFERENCES}

Abo El-Nil, M. Organogenesis and embryogenesis in callus cultures of garlic (Allium sativum L.). Plant Sci. Lett. 9:259-264; 1977.

Barrueto Cid, L. P.; Illg, R. D. Suspensão celular em alho (Allium sativum L.) e proposta de um método mais simples para avaliar seu crescimento. Ciênc. Cult. (Suppl) 42:476; 1990.

Berlyn, M. B.; Zelitch, I. Photoautotrophic growth and photosynthesis in tobacco callus cells. Plant Physiol. 56:752-756; 1975.

Besse, I.; Verdeil, J. L.; Duval, Y., et al. Oil palm (Elaeis guineensis Jacq.) clonal fidelity: endogenous cytokinis and indoleacetic acid in embryogenic callus cultures. J. Exp. Bot. 43:983-989; 1992.

Blom, T. J. M.; Kreis, W.; van Iren, F. A non-invasive method for the routine-estimation of fresh weight of cells grown in batch suspension cultures. Plant Cell Rep. 11:146-149; 1992.

Chowdhury, M. K. U.; Vasil, I. K. Stably transformed herbicide resistant callus of sugarcane via microprojectile bombardment of cell suspension cultures and electroporation of protoplast. Plant Cell Rep. $11: 494-498 ; 1992$.

Dubois, J.; Droujininski, A.; Vasseur, J. Croissance et potentialités organogènes de suspensions cellulaires de Cichorium intybus $\mathrm{L}$. var. Witloof. Bull. Soc. Bot. Fr. Lett. Bot. 135:311-322; 1988.

Evans, P. T.; Malmberg, R. L. Do polyamines have roles in plant development? Annu. Rev. Plant Physiol. Plant Mol. Biol. 40:235-269; 1989.

Havránek, P.; Novák, F. J. The bud formation in callus cultures of Allitum sativum L. Z. Pflanzenphysiol. Bd. 68:308-318; 1973.

Horsch, R. B. Quantitative plating technique. In: Vasil, J. K., ed. Cell culture and somatic cell genetic of plants. Orlando, FL: Academic Press; 1984:192-198.

Husemann, W.; Barz, W. Photoautotrophic growth and photosynthesis in cell suspension cultures of Chenopodium rubrum. Physiol. Plant. 40:77-81; 1977.

Illg, R. D.; Siqueira, W. J. Variação somaclonal em alho. Inf. Agrop. Belo Horizonte 12:12-17; 1986. 
Kathoh, K.; Ohta, Y.; Hirose, Y., et al. Photoautotrophic growth of Marchantia polymorpha L. Cells in suspension culture. Planta 144:509-510; 1979.

Kehr, A. E.; Schaeffer, G. W. Tissue culture and differentiation of garlic. Hortscience 11:422-423; 1976.

Murashige, T.; Skoog, F. A revised medium for rapid growth and bioassays with tobacco tissue cultures. Physiol. Plant. 15:473-497; 1962.

Nagasawa, A.; Finer, J. J. Development of morphogenic suspension cultures of garlic (Allium sativum L.). Plant Cell Tissue Organ Cult. 15:183-187; 1988.

Novák, F. J.; Havránek, P. Attempts to overcome the sterility of common garlic (Allium sativum L.). Biol. Plant. 17:376-379; 1975.
Novák, F. J. Production of garlic (Allium sativum L.) tetraploids in shoot-tip "in vitro" culture. Z. Pflanzenzuchtg. 91:329-333; 1983.

Novák, F. J.; Havel, L.; Dolezel, J. Allium. In: Sharp, W. R.; Ammirato, P. V.; Evans, D. A., et al. Handbook of plant cell culture. New York: Mcmillan; 1985:419-456.

Schmitz, U.; Lörz, H. Nutrient uptake in suspension cultures of gramineae. II. Suspension cultures of rice (Oryza sativa L.) Plant Sci. 66:95$111 ; 1990$.

Smolenskaya, I. N.; Nosov, A. V.; Raldugina, G. N. Broad bean cell suspension culture. Soviet Plant Physiol. 35:946-952; 1989.

Vince-Prue, D. Photoperiodism in plants. London: McGaw-Hill, 1975:385-405. 